\title{
MOOC som studievalgsvejledning, læringsobjekt og redskab i markedsføring
}

\section{Simon B. Heilsen}

\section{Lektor}

Enhenden for akademisk efteruddannelse, Akademisk IT, Institut for Psykologi og Uddannelsesforskning, Roskilde Universitet.

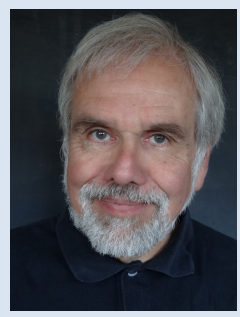

Simon Heilesen er lektor ved Institut for Psykologi og Uddannelsesforskning, Roskilde Universitet. Han er tilknyttet enheden for Akademisk Efteruddannelse (EAE), hvor han arbejder med Akademisk IT, dvs. forskning, formidling og undervisning med inddragelse af digitale medier. Aktuelt arbejder han med læringsrum (fysiske og virtuelle) og med digital dannelse $i$ forbindelse med uddannelses- og velfærdsteknologier, bl.a. med et projekt om hvordan studerende anvender IT i projektarbejdet. 


\section{Abstract}

MOOCs (Massive Open Online Course) har vundet international udbredelse som uddannelses- og formidlingsplatforme, hvor læreanstalter gratis eller for en beskeden pris stiller deres viden til rådighed for den brede offentlighed af internet-brugere. Det frie udbud af undervisning af høj kvalitet er samtidig med til at markedsføre uddannelsesinstitutionerne. Dette synes især at komme eliteuniversiteterne til gode (Kedem \& Puchalla, 2012). Men andre kan sagtens være med, når blot de finder anvendelser, som ikke er i direkte konkurrence med eliten.

Denne artikel beretter om et forsøg på at skabe en niche-anvendelse af M00Cs. Forøget har været udført inden for rammerne af forsknings- og udviklingsprojektet Læring uden grænser (LUG), der blev gennemført 20132015 i et samarbejde mellem University College Sjælland og Roskilde Universitet og med støtte fra Den Europæiske Fond for Regionaludvikling. Projektets formål har været at udvikle og formidle ny viden om, hvordan digitale teknologier og nye koblinger i form af netværk- og institutionssamarbejde kan mindske grænser for læring på regionalt niveau. Projektet har været inddelt i fire delprojekter, hvoraf det, der skal redegøres for i det følgende, har haft som mål at forske i og udvikle en regionalt orienteret MOOC, der kan tilbyde gratis efter- og videreuddannelse målrettet medarbejdere ansat i virksomheder med fokus på velfærdsydelser i Region Sjælland. MOOC-platformen, som de her beskrevne forsøg har været en del af, har været gjort tilgængelig på URL'en www.moocz.dk (URL'en benyttes i fremtiden af Den Sjællandske Uddannelsesportal).

Idéen bag de forsøg på Roskilde Universitet, som artiklen redegør for, er at undersøge, hvordan det er muligt at formidle et universitets faglighed dels til en primær målgruppe af potentielle studerende, som derved får et tilbud om at kvalificere studievalget. Dels til medarbejdere i virksomheder og organisationer, som kan drage nytte af den viden, universitetet stiller til rådighed.

I det følgende skitseres først den studievalgs- og frafaldsproblematik, som har inspireret til forsøgene. Dernæst præsenteres M00C-fænomenet, og forsøgskonceptet uddybes og sammenlignes med tilsvarende anvendelser af MOOCs. Efter denne rammesætning følger en redegørelse for udviklingen og afprøvningen af de to uddannelsesdesigns, der har været arbejdet med. Da der er tale om to begrænsede og kortvarige forsøg, må vurderingen af effekten af forsøgene nødvendigvis være tentativ.

\section{Studievalg og frafald}

Hvor meget vidste du på forhånd om den uddannelse, du i sin tid søgte ind på? Hvis spørgsmålet gør dig lidt ulden i mælet, er du ikke alene. Mange unge påbegynder nemlig en videregående uddannelse med ret vage 
forestillinger om, hvad studiet faktisk indebærer. Det på trods af, at gymnasier og HF tilbyder vejledning i studievalg, at læreanstalterne afholder besøgsdage og informerer på forskellig vis, og at der findes gode studievalgsressourcer på nettet, først og fremmest

Undervisningsministeriets Uddannelsesguiden (www.ug.dk). Ofte oplever nye studerende, at den indledende begejstring over det at studere et fag, man selv har valgt, afløses af en hverdag på studiet med hårdt arbejde og trælse fag, som bringer tvivlen frem, om man nu også har valgt rigtigt.

Ganske mange tvivlere indser, at der er grund til at vælge om, hvis de ikke er i stand til at udvikle en strategi til at overvinde kløften mellem forventningerne til og oplevelsen af studiet (Holmegaard, Madsen \& Ulriksen, 2014). På kandidatuddannelserne falder hver sjette studerende fra hen over en femårs periode - et betragteligt antal om end lavere end frafaldet på professionsuddannelser og erhvervsakademiuddannelser (van Deurs, 2013). Størstedelen af frafaldet indtræffer i løbet af det første studieår, og hovedparten af det skyldes studieskift. Samfundsøkonomisk er det et ikke helt ubetydeligt problem, og allerede i 2006 fik universiteterne gennem Velfærdsaftalen pligt til at tage sig af frafaldstruede studerende, samtidig med at taxametersystemet blev ændret, så det præmierede studiegennemførelse (Finansministeriet, 2006, s. 59 ff.). Med indfasningen af den såkaldte Studietidsmodel i 2015 til 2020 bliver nedbringelse af studietiden en kontant udfordring for universiteterne, idet en betydelig færdiggørelsesbonus gøres afhængig af, at universiteterne nedbringer studietiden med i gennemsnit 4,2 måneder (Schmid, 2013). Universiteterne er således blevet underlagt et "fremdriftsorienteret regime", hvor styring af tid har afgørende betydning (Sarauw, 2014).

Ministeriet for Børn og Undervisning har gennem en årrække undersøgt, hvilke faktorer der forlænger uddannelserne (Henriksen, 2013). Tallet for studieskift har ligget stabilt på fem måneder ud af de gennemsnitligt 42 måneders mertidsforbrug (dvs. overskridelse af normeret studietid) på vejen fra 9. klasse til opnået erhvervskompetence. Fraregner vi 10. klasse (6 mdr.), uddannelsespause ( 24 mdr.) og den såkaldte dobbelte ungdomsuddannelse (3 mdr.), vejer studieskift således ganske tungt. Det er nogle dyre måneder både for de unge selv, fordi de spilder SU-klip og i en del tilfælde oplever et personligt nederlag, og også for læreanstalterne der bruger studiepladser og ressourcer på undervisning uden at kunne hente taxameterpenge hjem, og hvis planlægning lider under frafaldet.

Der er mange årsager til frafald på de videregående uddannelser (Ulriksen, Madsen \& Tolstrup, 2011). Evner, motivation og sociale vilkår vejer naturligvis tungt, men forskningen peger også på, at de studerendes arbejde med at skabe en identitet i forhold til faget og opnå faglig integration har betydning. Holmegaard, Madsen \& Ulriksen (2014) diskuterer tre strategier til at bygge bro over kløften mellem 
forventningerne til studiet og den virkelighed, som den studerende møder: at holde ud med blik på erhvervsmulighederne, at tilpasse sig studiet ved at anlægge forskellige studiestrategier, samt at tilpasse sin identitet til studiet og opnå en fornemmelse af at høre til. MOOC-forsøgene tager udgangspunkt i tanken om "tilpasning", men kombinerer den med en anden kendt faktor for studiegennemførelse, nemlig studieforberedelse. Ikke i forstand af egentlig kvalificering som eksemplificeret ved Advanced Placement, der omtales nedenfor, men i form af forbedret kommunikation mellem universitet og vordende studerende. Antagelsen er, at et mere kvalificeret studievalg meget vel kan have betydning for gennemførselsprocenten på uddannelserne.

Det skal således foreslås, at man ved tidligt at give bedre indblik i uddannelserne kan hjælpe med til at forebygge frafald. Der vil være tale om et supplement til mere konventionel studievalgsvejledning samt til indgriben under studiet, enten ved studievejledere på faget eller gennem nye, statistiske "big data" metoder (academic analytics eller learning analytics; se fx Siemens \& Long, 2011; van Barneveld, Arnold \& Campbel, 2012; Baker \& Siemens, 2014). En effekt af større målrettethed og mindre frafald blandt de studerende (og dermed et reduceret behov for undervisningsdifferentiering) vil forventeligt også være et generelt løft i kvaliteten af undervisningen.

Intet af det ovennævinte kan godtgøres uden omfattende longitudinale studier, og nærværende artikel har således blot til formål at præsentere et koncept for, hvordan man kan gribe problemet an. Det er udmøntet i to prototyper, som er blevet udviklet i nært samarbejde med slutbrugere, og som har været igennem en afprøvning, der gav forholdsvis opmuntrende resultater. Som udviklingsmetode har været anvendt firefeltmodellen for brugerdrevet innovation (Helms \& Heilesen, 2011).

Massive Open Online Course (MOOC) er et noget forkætret begreb, som siden lanceringen i efteråret 2008 har udviklet sig i to retninger. Den ene har holdt fast i den oprindelige idé om at skabe et læringsværktøj til at understøtte en særlig pædagogisk tilgang, der kendes som konnektivisme, og som (forenklet) hævder, at læring skabes gennem udvikling af netværk, hvis knuder (bestanddele) kan være snart sagt hvad som helst: tekster i enhver forstand, personer, institutioner, mm. (Siemens, 2005; 2006). Den anden retning har ved at kombinere den oprindelige MOOC-idé med traditionen for åben uddannelse samt med åbne læringsressourcer (Open Educational Resources, OER) og Khan Academy's massive netbaserede distribution af video-læringsobjekter (Khan, 2011), udviklet den form for netbaseret læring, de fleste i dag forbinder med begrebet MOOC. Realiseret i kommercielle læringsplatforme såsom Udacity (den oprindelige af slagsen), Coursera (som benyttes af flere danske universiteter), $E d X$ (drives af eliteuniversiteterne MIT og Harvard), Iversity (europæisk), mfl. tilbydes 
undervisning, som er åben, dvs. frit tilgængelig for alle interesserede, massiv, i den forstand, at der i princippet kan være ubegrænset mange deltagere, online i og med at den er rent netbaseret samt som oftest kursusorienteret, udsprunget som fænomenet jo er af en angelsaksisk undervisningstradition.

Der er en gradsforskel mellem det nye fænomen MOOC, i den sidste de af ovennævnte former, og så diverse andre og længe praktiserede former for netbaseret undervisning, men der er ikke tale om en helt "ny" måde at undervise på. Det handler snarere om, at MOOCs som benyttet indtil videre repræsenterer en friere måde at formidle faglig viden på. Det er et synspunkt, som understøttes dels af gennemførselsprocenten for MOOCkurser (omkring 7\%; Ho et al, 2014; Jordan, 2013; Perna et al, 2013), dels af undersøgelser af deltagernes motivation, hvor nysgerrighed scorer højere end karriereudvikling (Perna et al., 2013; University of Edinburgh, 2013), og dels af det faktum, at MOOC-kurser ofte introducerer til et fagområde, men, endnu i hvert fald, sjældent udbydes som en progression af kurser, der fører frem mod en komplet uddannelse. I en tid hvor information er noget, man gerne googler sig til med mere eller mindre tilfældige og sommetider uoverskuelige resultater, er det nærliggende at antage, at MOOC'en har en særlig attraktion ved at tilbyde den seriøst interesserede bruger let adgang til veltilrettelagt og velunderbygget information på et højt niveau.

Med dette in mente er der i M0OC-forsøgene valgt at informere om uddannelser snarere end at tilbyde samlede forløb, og ved at begrænse den intenderede målgruppe til regionens borgere (potentielt også andre danske internet-brugere) er idealet om ubegrænset tilgængelighed fraveget. Der er dermed tale om ROOCs, Regional Open Online Courses, et begreb som trods det lidt letbenede ordspil, kan beskrive initiativer, hvor regionale institutioner søger at betjene deres naturlige opland. Det massive i undervisningstilbuddet skal i den aktuelle sammenhæng forstås som størrelsen på de nævnte målgrupper sammenholdt med antallet af indskrevne studerende på de uddannelser, som har leveret kurser til forsøgene. En tredje væsentlig afgrænsning gælder platformen, hvor der er brugt e-læringsværktøjet Moodle frem for en af de kommercielle platforme. Dette er begrundet i hensyn dels til institutionens økonomi og dels til håndtering af undervisernes og deltagernes intellektuelle rettigheder, som kan være vanskelige at håndhæve på de kommercielle MOOC-platforme. Men samtidig har det også været ambitionen at demonstrere, at MOOCs ikke er afhængige af en bestemt platform. Faktisk ville man kunne udbyde en MOOC ved hjælp af noget så simpelt som en weblog. Men det skal naturligvis erkendes, at de store, professionelle systemer har mange nyttige funktionaliteter, som ikke nødvendigvis er til rådighed på andre platforme. 


\section{Konceptet kort}

Roskilde Universitet har inden for rammerne af LUG-projektet eksperimenteret med at levere en ny form for studievalgsvejledning, der skal give kommende studerende et nogenlunde realistisk indtryk af, hvad det vil sige at læse et fag på universitetet. Med det overordnede formål, som er at hjælpe uddannelsessøgende med at træffe et mere kvalificeret studievalg, følger tre underordnede, men også væsentlige formål.

For det første: Da studievalgsvejledningen er udformet som et kursus, har det været nærliggende at tilpasse dette, så det vil kunne bruges som et læringsobjekt i undervisningen i gymnasiet/HF. Projektet har dermed haft en ambition om at anvise en måde at bygge bro mellem de sekundære og tertiære uddannelsesniveauer. Men der er ikke indgået overvejelser om sammenhængen med eller betydningen for det kommercielle marked for lærebøger og undervisningsmaterialer.

For det andet: Givet at kurserne er åbne for alle interesserede, repræsenterer de også en måde, hvorpå universitetet kan informere generelt om sit virke samt leve op til sin forpligtelse til at formidle viden til samfundet. Det ene af de to forsøg, som omtales i det følgende, er i høj grad designet med henblik på netop at kommunikere ekspertviden til offentligheden. Men inden for projektets rammer har det ikke været muligt i praksis at afprøve denne form for generel, åben formidling.

For det tredje: Med mellemrum vækker det opsigt, hvor mange penge læreanstalterne bruger på markedsføring af deres uddannelser (se fx Rottbøll, 2012; Hjortdal, 2014). I den voksende konkurrence mellem uddannelsesinstitutionerne er markedsføringstiltag uomgængelige. Men der er forskellige måder at reklamere på. Anskuet som markedsføring må initiativer i stil med det aktuelle forsøg med studievalgsvejledning anses for høre til i den seriøse ende, hvor der ud over et fagligt ambitionsniveau også er tænkt på at anvende ressourcerne på en samfundsmæssigt ansvarlig måde. Dermed ikke sagt, at det er billigt. Som delvist finansieret udviklingsforsøg har projektet kunnet bruge de midler, der var nødvendige for at opnå et godt resultat. Men det kan konstateres, at udviklingsomkostningerne har været betydelige, samt at der løbende skal afsættes midler, hvis denne form for kurser skal indgå i universitetets ordinære drift, også selv om det én gang udviklede materiale med løbende tilpasninger formodentlig vil kunne genbruges i en årrække.

\section{Lignende koncepter}

Det M00C-koncept, der er udviklet på Roskilde Universitet som en del af LUG-projektet, er i skrivende stund unikt herhjemme, og internationalt findes der kun ganske få eksempler på en tilnærmelsesvis tilsvarende måde at gribe studievalgsvejledning an. Men selve idéen med at lade udenforstående få et indtryk af en uddannelse eller et videnskabeligt felt er 
bestemt ikke ny. I Danmark repræsenterer Folkeuniversitetet en mere end 100-årig tradition (Albeck, 1984), ligesom faglig formidling til voksne har været praktiseret i årtier af oplysningsforbundene.

På internettet blev adgangen til undervisning på universitetsniveau for alvor åbnet for alle i 2004 med introduktionen af begrebet podcasting (Heilesen, 2012). Mange universiteter verden over driver i dag selv videoarkiver eller benytter Apples iTunes-tjeneste eller lægger materialer ud på en video-portal som fx. YouTube. Der er meget at vælge imellem, og et gennemgående træk er, at det er institutionen, som formidler på institutionens præmisser (omend gerne populariserende) uden at henvende sig til en nærmere defineret målgruppe. For podcasts (såvel audio som video) gælder, at der er tale om optagelser enten af undervisningssituationer eller af undervisere, som taler direkte til den lærende uden mulighed for interaktion. Det er mindre almindeligt, at en samling podcasts udgør et sammenhængende, længerevarende uddannelsesforløb, omend eksempler naturligvis forekommer, bl.a. Yaser Abu-Mostafa's Machine Learning Course - CS156, der er tilgængeligt iTunes og på YouTube og som til dato har været set, i hvert fald i uddrag, af mere end 200.000 brugere (kursus-websted: work.caltech.edu/telecourse.html; videoer: https://www.youtube.com/playlist?list=PLD63A284B7615313A). Netop Machine Learning kurset har været brugt systematisk af det amerikanske California Institute of Technology, til at fremme forståelsen af ingeniørvidenskaben, bl.a. for kommende studerende, der ikke sjældent oplever vanskeligheder under studieforløbet, fordi de på forhånd ved for lidt om, hvad faget går ud på. Eksemplet er således beslægtet med Brown University's Exploring Engineering -MOOC, der i skrivende stund er det undervisningskoncept, som kommer nærmest på RUC's MOOC-forsøg.

Exploring Engineering er et er to-ugers kursus, som Brown University, USA, udbød første gang i efteråret 2013 (Ferdig, 2013; Frenkel, 2013; Schulson, 2013; Wilner, 2013; for 2015-udgaven af kurset, se:

www.brown.edu/ce/precollege/catalog/course.php?course_code=CEEN0914). Det indgår som en del af universitetets betalings pre-college programs (nogenlunde modsvarende "sommerskole", og ikke adgangsgivende), eller rettere det er en gratis forløber for de egentlige pre-college kurser i ingeniørvidenskab. Hensigten med det er at introducere de studerende til uddannelsen og dens faglige specialiseringer. Ud over at stimulere interessen for faget er målet at hjælpe de studerende med at vælge den rigtige linje på ingeniørstudiet, idet erfaringen er, at et stort antal studerende skifter linje efter studiestart, samt at en del falder helt fra. Exploring Engineering henvender sig til high school elever, men alle kan frit tilmelde sig de 500 pladser, som udbydes pr. forløb. 
På det sekundære uddannelsestrin har MOOC allerede fundet anvendelse på en række måder, der enten fokuserer på det aktuelle uddannelsestrin eller på elevernes videregående uddannelse (Bull, 2013; Jackson, 2013). Her følger en kort oversigt over tre hovedanvendelser:

\section{Kvalificering til videregående uddannelse}

Med henblik på videreuddannelse eksisterer allerede i USA og Canada begrebet Advanced Placement (AP). Det er et program, som udbyder kurser inden for mange forskellige fag på universitetsniveau, men som er målrettet til high school elever. Beståede prøver kan lette optagelsen på et universitet og giver i visse tilfælde studiepoints (credit). I denne sammenhæng optræder MOOCs blot som et alternativt medium til i øvrigt velkendte typer af undervisning. Datalogikurset Amplify MOOC, nu Edhesive, er et af de første eksempler på, at et MOOC-kursus kan godskrives i en universitetsuddannelse (https://edhesive.com/).

Mere generel universitetsforberedende undervisning (college readiness), optræder som kurser i almene færdigheder (læsning, skrivning og matematik; se fx. University of Wisconsin: http://www.uwlax.edu/mathmooc/ og Broward College: http://www.skillacademy.com/course/692/Canvas/College-FoundationsReading-Writing-and-Math/) eller i bestemte fag, som er grundlæggende vigtige for et studium, fx. humanbiologi som grundlag for sundhedsuddannelser (se fx Le Collège de Rosemont: http://ouvert.cegepadistance.ca/). Kurserne lader dels deltagerne afprøve, om deres kundskaber er tilstrækkelige til at læse på universitetsniveau, dels medvirker de til at bringe kundskaberne op på det nødvendige niveau. Kurser af denne type forventes af udbyderne at kunne nedbringe frafald på studierne. Dette er således rationalet for Brown University's ovenfor omtalte M00C, Exploring Engineering. Selv om de ikke er direkte fagligt forberedende, skal også nævnes MOOC-kurser i at skrive gode ansøgninger til videregående uddannelser. Et eksempel er Udemy's kursus The College Application (http://www.skillacademy.com/course/1112/udemy/TheCollege-Application/).

\section{Integration i sekundær uddannelse}

En anvendelse af MOOCs på det sekundære uddannelsesniveau kobler MOOC-kurser sammen med den konventionelle undervisning, enten som læremidler eller som supplement til fagudbuddet. Ved integration i den eksisterende undervisning er der tale om en form for blended learning, hvor kurser eller dele af kurser, som udbydes af videregående uddannelser, integreres i skolernes undervisning. Det sker gerne på initiativ fra den enkelte lærer, som får en klasse eller en gruppe af elever til at tilmelde sig og derefter inddrager MOOC'en i egen undervisning. En variant af denne model omfatter undervisningsdifferentiering, som gøres mulig ved at lade en gruppe elever arbejde med en MOOC, enten for at bringe dem op på 
niveau eller for at give ekstra muligheder til dygtige elever. Der findes også fors $ø$ g med at lade elever med særlige behov arbejde med M00Cs (fx en autistisk elev, University of Edinburgh, 2013, September 16).

De MOOCs, som finder anvendelse i ungdomsuddannelserne, omfatter som regel undervisning, der alligevel tilbydes på nettet, og som kan tilpasses en skoleklasse. Et videre perspektiv med MOOCs er naturligvis, at lærere på tværs af skoler finder sammen om at opbygge og udbrede gode undervisningsmaterialer. Der kan være tale om en ressourcebank eller om et egentligt samarbejde mellem undervisere om at udvikle og anvende materialer. Ud over det indlysende mål, som er at skabe kvalitet, byder sådanne initiativer også på samdrift og dermed rationalisering. Fortilfælde findes fra brug af andre medier, fx. wikis til at fællesudvikle undervisningsmaterialer på nettet (se fx. http://en.wikiversity.org/). Blandt M00Cs og M00C-lignende initiativer kan fremhæves Curriki (http://www.curriki.org/) og det tidligere omtalte Khan Academy (https://www.khanacademy.org/).

Som supplement til undervisningen kan MOOC-kurser bidrage med fordybelse i emner, som normalt ikke udbydes på en given skole, og sådanne kurser kan evt. godskrives. Et amerikansk eksempel fra Andover, Massachusetts, beskriver, hvordan tre MOOCs fra EdX-platformen har været brugt til at udbyde undervisning i græsk mytologi, jura og biologi på højt niveau (Jackson, 2013). Ideen med at supplere undervisning via netbaseret læring har været praktiseret længe før, M00Cs kom i vælten ( $\mathrm{fx}$ Lawson \& Comber, 2010; Pritchard, Hunt \& Barnes, 2010). Ikkeformaliseret supplement til undervisningen hører med til billedet. Det kan dreje sig om selvstudier, hvor elever enten følger et MOOC-kursus, fordi emnet interesserer dem, eller fordi de kan bruge dele af materialet i et projekt, eller som en generel lektiehjælp i et fag, som eleven gerne vil blive dygtigere til; eller blot for at opbygge et netværk.

\section{Rent M00C-baseret uddannelse}

Der findes eksempler på udbud af en komplet uddannelse via en MOOC (fx. University of Miami, Global Academy: http://globalacademy.miami.edu/). Her, som i andre eksempler, er MOOC'en et nyt medium, men formen med et "studenterkursus" via fjernundervisning er langt fra ny.

\section{Roskilde Universitets MOOCs}

LUG-projektets RUC-MOOC koncept er blevet mødt med interesse og anerkendelse af de undervisere på universitetet, der er blevet præsenteret for det, og fire - fem praktiske forsøg har været drøftet. Det nødvendige tidsforbrug på en udviklingsopgave, som ikke har umiddelbar anvendelighed i den aktuelle undervisning på RUC, har imidlertid været et væsentligt problem, og i praksis har det kun været muligt at bringe to 
koncepter videre end idéplanet. De repræsenterer til gengæld to ret forskellige designs.

\section{SEM-MO0C konceptet}

Social Entrepreneurship and Management (SEM) er en international kandidatuddannelse, som udbydes på engelsk (se: http://www.ruc.dk/uddannelse/fag/socialt-entreprenoerskab-ogmanagement/). Den har som formål at uddanne kandidater, der kan initiere, implementere og lede sociale innovationer med henblik på at skabe bæredygtige løsninger på sociale og samfundsmæssige udfordringer. Uddannelsen er tværdisciplinær og bygger både på klassiske samfundsvidenskabelige discipliner som sociologi og økonomi og nyere forskning i social innovation, socialt entreprenørskab, Corporate Social Responsibility, forretningsplan, sociale og finansielle regnskaber samt ledelse og management. I uddannelsen lægges der vægt på styrke evnen til at tænke innovativt, interdisciplinært og på tværs af samfundets traditionelle sektorer samt på motivation for at ville bidrage til at skabe bæredygtig social forandring. Kandidater vil typisk enten starte nye, innovative foretagender op, finde beskæftigelse i socialøkonomiske virksomheder eller i offentlige og private organisationer, hvor de kan bidrage til at skabe sociale innovationer. SEM-uddannelsen er således valgt som case, dels fordi et kursus i socialt entreprenørskab må antages at have noget nyt og udfordrende at føje til undervisningen i samfundsfag $\mathrm{i}$ gymnasiet og HF; og dels fordi orientering i emnet via en MOOC også er relevant for en eventuel bredere målgruppe af medarbejdere i offentlige og private virksomheder og organisationer.

SEM-MOOC har været igennem en iterativ udviklingsproces, hvor idégrundlaget blev udviklet i et samarbejde mellem en professor ved faget og RUC's akademisk IT, der hjælper med at udvikle og understøtte ITløsninger til opgaver inden for forskning, formidling og undervisning. Dernæst blev der udviklet et første konkret design med værdifuld medvirken af adjunkt Jesper Stage Petersen fra UC Sjællands læreruddannelse, der siden også varetog opgaven med at lede evalueringen af kurset. Designet i form af en kørende prototype blev derefter præsenteret for en gymnasielektor, og i lyset af hans diskussioner med især UC Sjællands pædagogiske ekspert blev det endelige kursus udformet (Figur 1). 


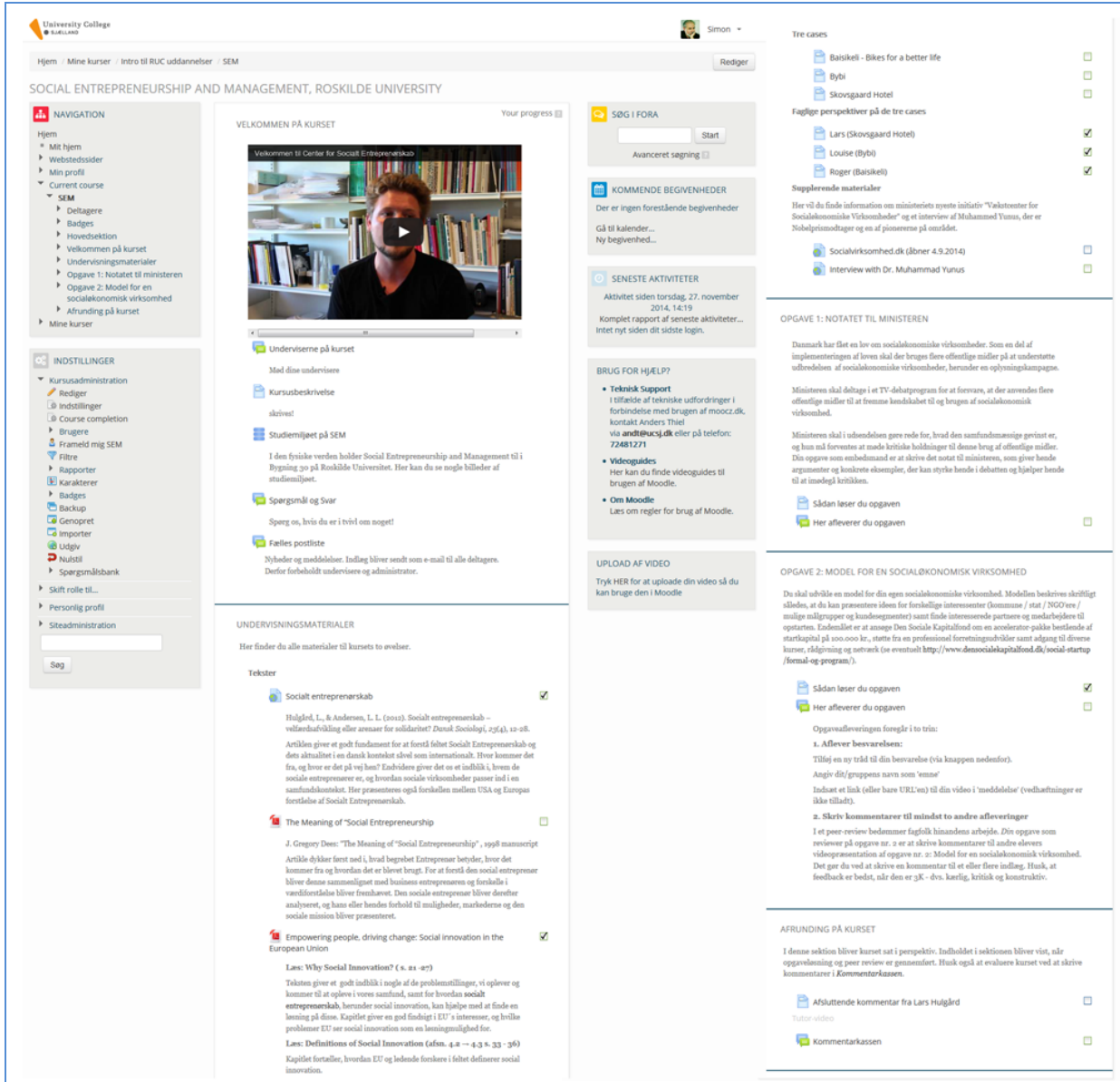

Figur 1 SEM-MOOCs hovedside.

SEM-MOOC blev bygget op som en smagsprøve på selve uddannelsen. To hovedprincipper har guidet den faglige og didaktiske opbygning af M00C'en. For det første skulle niveauet passe med samfundsfag på Aniveau i 3.G. Som nævnt blev dette sikret gennem et tæt samarbejde med den gymnasielektor, hvor forsøget blev afprøvet. For det andet ønskede vi, at eleverne skulle få en prøve på den interaktive læringsmodel, som både er et af Roskilde Universitets karakteristika, og som SEM-uddannelsen konstant forsøger at nytænke ved at inddrage processer af samskabelse i undervisningen. Dette blev i SEM-MOOC'en designet som et dobbeltspor bestående af:

1. En del, som primært bestod af viden og vidensbearbejdning. Den omfattede en lille samling af tekster, tre korte videoer med henholdsvis eksempler på socialt entreprenørskab og tre kommentarer til disse ved SEM-undervisere, samt en skriftlig opgave, hvor eleverne skulle skrive et notat om socialt entreprenørskab. Opgaven skulle afleveres i MOOC'en hvor den blev kommenteret af kursus-instruktoren Jakob, der var kursets gennemgående "menneskelige ansigt", samt af eleverne selv igennem en gensidig bedømmelse (peer assessment). Aktiv deltagelse i gensidig bedømmelse var obligatorisk på kurset. 
2. En efterfølgende del, hvor deltagerne selv skulle skabe et produkt i form af en konkret idé til socialt entreprenørskab. Denne skulle præsenteres gennem en kort video, inspireret af præsentationsformen "pitch" eller "elevatortale", og også denne skulle afleveres i MOOC'en til kommentering af instruktor og de øvrige kursusdeltagere.

En egentlig faglig bedømmelse af elevernes indsats blev overladt til gymnasielæreren, i hvis fag kurset indgik, mens instruktorens kommentarer og en opsummerende video ved en af fagets professorer havde form af en konstruktiv kritik, der skulle motivere eleverne og anvise veje til at arbejde videre med stoffet.

\section{HumTek-M00C konceptet}

Den humanistisk-teknologiske bacheloruddannelse (HumTek, se: http://www.ruc.dk/uddannelse/bachelor/humanistisk-teknologiskbacheloruddannelse/) beskæftiger sig med, hvordan mennesker anvender den teknologi, som omgiver os. Det er en meget udviklingsorienteret uddannelse, hvor de studerende arbejder med at frembringe innovative designs til gavn for arbejdsliv, hverdagsliv og miljø. Til uddannelsen er knyttet et FabLab, som er et laboratorium for rapid prototyping metoder (om FabLabs se fx.: Walter-Herrmann \& Büching, 2013). Der udvikles såvel digitale produkter som fysiske artefakter, og der både programmeres på computer og arbejdes med avanceret udstyr såsom 3D-printere og laserudskærere. FabLab bruges intensivt af HumTek-studerende, men det er åbent for alle interesserede, og det er laboratoriets ambition at knytte kontakt med regionale iværksættere samt vordende iværksættere.

En barriere for at anvende FabLab er, at det kræver nøje instruktion at betjene det meget avancerede og i nogle tilfælde farlige apparatur, der er opstillet i laboratoriet. For de HumTek-studerende bliver der hvert semester afholdt forskellige obligatoriske kurser som optakt til workshops og projektarbejde, mens udefra kommende er henvist til at få instruktion af en FabLab-medarbejder, når de møder frem. Det er derfor nærliggende at udvikle læringsobjekter, som kan hjælpe eksterne brugere såvel som indskrevne studerende, der på grund af sygdom mv. ikke har deltaget i et kursus, eller som har brug for en repetition. Samtidig er det tanken, at læringsobjekterne skal hjælpe med at markedsføre FabLab over for regionens borgere som en åben og gratis ressource, de er velkomne til at benytte sig af. 


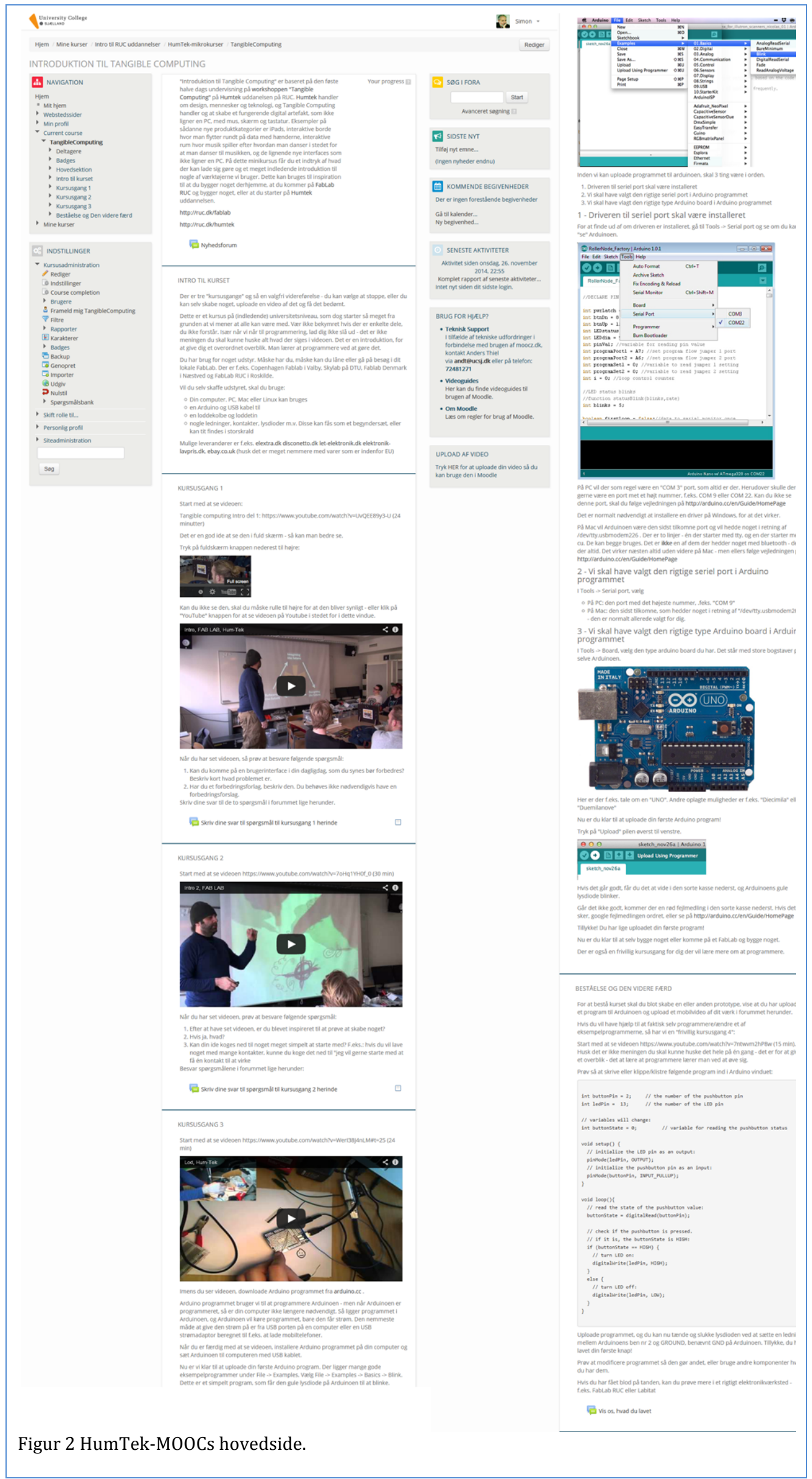


Sammen med FabLab-personalet blev der planlagt tre "mikro-kurser" i Introduktion til processing, Processing for noget øvede, samt Introduktion til tangible computing. På grund af travlhed på FabLab blev kun det sidste af disse kurser implementeret som en MOOC (Figur 2). MOOC-versionen af Introduktion til tangible computing er en bearbejdning af den første halve dags undervisning på HumTek-workshoppen Tangible Computing, der har som mål, at deltagerne skal frembringe et fungerende, digitalt artefakt, som ikke må ligne en konventionel PC. MOOC'en er opbygget som tre kursusgange, deltageren kan "tage" i sit eget tempo. I modsætning til SEMMOOC'en kan deltagerne her påbegynde kurset når som helst og afslutte, når det passer dem. De to første kursusgange er baseret på videoer af forelæsninger på workshoppen om afgrænsede emner, som MOOCdeltageren efterfølgende selv kan afprøve. Den tredje kursusgang instruerer i lodning og forudsætter, at deltageren efterfølgende møder op i FabLab for også praktisk at øve lodning. Beståelseskriteriet for kurset er, at deltageren udvikler et produkt, enten på FabLab eller en anden lokalitet, og producerer og indsender en videooptagelse om produktet. Denne bliver til slut kommenteret af en FabLab-medarbejder samt andre kursusdeltagere.

\section{Den praktiske afprøvning}

\section{SEM-MOOC afprøvningen}

Kurset i Socialt Entreprenørskab blev afprøvet på et storkøbenhavnsk gymnasium i efteråret 2014. 26 elever i en 3.G-klasse med Samfundsfag på højt niveau arbejdede med stoffet fra ugen før efterårsferien og frem til midten af november under ledelse af deres samfundsfagslærer. Underviseren havde frie hænder til at inddrage læringsobjektet i sin undervisning, og det kom i høj grad til at foregå offline. MOOC'en blev overvejende anvendt som arkiv, hvor eleverne kunne hente litteratur og opgaver for siden at uploade de to obligatoriske afleveringer til henholdsvis bedømmelse ved kursets instruktor og til gensidig kommentar (peer assessment). Det lykkedes således kun at skabe et online-miljø i korte perioder i forbindelse med afleveringerne, og interaktionerne begrænsede sig næsten udelukkende til afleverings-feedback mellem henholdsvis elevinstruktor og afleverende og kommenterende elev(er).

Til gengæld fik læreren mulighed for at tilrettelægge undervisningen præcis, som han gerne ville, og vi vurderer, at det har haft afgørende betydning både for hans accept af MOOC'en og engagement i at bruge læringsobjektet samt for det vellykkede udfald af undervisningen, som elevernes evaluering vidner om.

Evalueringen blev gennemført som en Delphi-evalueringsundersøgelse, hvor eleverne først individuelt skulle besvare en række kvalitative spørgsmål i et skema om kursusforløbet, arbejdet med MOOC'en, udbyttet af kurset samt opnået kendskab til feltet socialt entreprenørskab. Dernæst 
skulle de, opdelt i to grupper på hver 13 elever, på spørgeskemaerne ved afkrydsning markere, om de var enige med svarene fra øvrige elever i gruppen. De mange kvalitative evalueringsudsagn blev på denne måde scoret kvantitativt, og det har dannet basis for at udtrække generelle holdninger. Citaterne i det følgende er udelukkende hentet blandt de udsagn, som bakkes op af mindst 9 ud af 12 mulige elevtilkendegivelser.

Konceptet med at anvende et læringsobjekt som supplement til studievalgsvejledning blev vel modtaget af så godt som alle. Adspurgt: "Hvis de uddannelser, som du er interesseret, i tilbød en 'smagsprøve' på at studere dem, hvordan ville du så benytte dette tilbud", var svarene positive, og som en elev uddyber det: "Det ville jeg klart benytte mig af, da det kan være svært at vide, hvad de forskellige uddannelser indeholder". En anden får en vurdering af lødigheden i studievalgsvejledningen med i sit udsagn: " jeg ville i høj grad benytte dem. Enhver uddannelse kan sælge sig selv, men spørgsmålet er om det faglige passer til en. Det minder mig om Oxfords online kurser, som jeg også har gjort brug af! :-)". Og en tredje føjer en væsentlig kvalificering til sit positive udsagn således: "jeg ville med glæde benytte denne metode igen. Specielt når det gælder et fag, man brænder for". En akilleshæl ved SEM-MOOC'en som læringsobjekt er naturligvis, at dens succes som en god oplevelse er betinget af interesse, hvad enten den findes på forhånd eller kan fremelskes. Imidlertid er en konstatering af, "at jeg nok ikke skal gå i den retning", ikke nødvendigt negativt, hvis oplevelsen med læringsobjektet har bidraget til at afklare elevens interesser.

Blandt eleverne var der meget høj grad af enighed om, at, kurset virkede motiverende - med mange udsagn, der indeholder ord som "interessant", "nyt", "relevant", "spændende", eller som en bramfrit skriver: "rigtig godt da pensum i gymnasiet ofte er kedeligt, fordi det 'bare giver igen'. Ét nyt kreativt og innovativt pust til pensum, OG DET ER TILTRENGT :-)". Man skal naturligvis ikke være blind for, at forandring fryder, og at der kan ligge et element af Hawthorne-effekt i de positive tilbagemeldinger: "god, da det var noget andet end den normale skoledag i samfundsfag". Men adskillige udsagn begrunder holdningen med dels det høje faglige niveau, bl.a. "gode tekster" og: "Det fungerede godt at blive undervist af en som vidste hvad han lavede", dels med undervisningsformen med gruppearbejde, og dermed større ansvar for egen læring: "at vi tog vores viden i brug og selv prøvede at udforme en socialøkonomisk virksomhed", samt med nogle lidt utraditionelle opgaver, ikke mindst, at "Pitch-talerne var fede". Og dels med, at der var et værdifuldt læringsudbytte i form af: "meget viden om socialøkonomiske virksomheder og deres funktion".

Trods den noget beskedne interaktion i MOOC'en fremgår det, at det har haft positiv betydning, dels "at lærerne gav deres vurdering/kommentarer derinde under ens aflevering" - med særlig ros til kursets instruktor: "stor interesse og engagement fra underviser" og " vi fik god og gennemarbejdet 
feedback, som kunne bruges". Dels, og måske ikke mindst, at eleverne har oplevet miljøet som transparent i og med, "at man kunne kommentere og læse hinandens opgaver", og hvor peer assessment beskrives som: "spændende funktioner såsom at kommentere på andres opgave". Alt i alt har interaktionen bevirket, "at man blev motiveret til at skabe et godt produkt, som man havde lyst til at præsentere". Interaktion er ikke MOOC'ens eneste attraktion for eleverne. Adskillige kommentarer går på, at det var godt, "at materialerne var på MOOC'en, vi fik noget $i$ hånden, hvilket gjorde opgaven mere overskuelig", samt at det er "rart at have alting samlet et sted så man faktisk ikke behøver videre søgning på nettet". Dette sidste udsagn, synes at bekræfte den tidligere nævnte anvendelse af MOOC som en bekvem måde at få organiseret og præsenteret viden på.

Til udsagnene om fagligheden hører også flere kommentarer om, at kurset har givet "et syn på hvad en universitetsopgave kunne ligne". Heri ligger en fare for, at eleverne identificerer kursets faglige niveau og tempo med arbejdsformen på universitetet. For netop gennem den brugerinvolverende forhandling om at skabe et produkt, som med sikkerhed kan anvendes $\mathrm{i}$ gymnasiet, er MOOC-kurset blevet bragt på et format og ambitionsniveau, som ikke afspejler typisk universitetsundervisning. Kurset er også blevet udbudt på dansk, mens den ordinære SEM-undervisning foregår på engelsk. Nedjusteringen har været en betingelse for underviser-accept af kurset, og besvarelserne vidner om, at den har været berettiget, idet mange taler om en udfordrende men passende sværhedsgrad, mens et mindretal (seks eller færre enige med en tilkendegivelse) finder kurset vanskeligt. Problemerne består især i sværhedsgraden på litteraturen, navnlig at noget af den er på engelsk, en for omstændelig formulering af opgaverne, samt det kan være svært at orienterede sig i MOOC'en.

Eleverne blev spurgt om, hvordan det var at arbejde med M00C'en, og her retter svarene sig dels mod indholdet og dels mod platformen. Som nævnt er der stor tilslutning til udsagn om, at det er behageligt, at alle materialer er samlet på ét sted, men der er også, som nævnt ovenfor, kritik af, at kurset var "kompliceret at finde rundt $i$, når man skulle frem og tilbage på siden" (en observation som støttes af flere udsagn, som færre end 8 tilslutter sig), ligesom der efterlyses et "mere livligt interface". På det praktiske plan er der énstemmig kritik af, at "brugernavnene var indviklede". Inden kurset blev samtlige elever oprettet som brugere og fik tildelt et brugernavn og password konstrueret ud fra deres for- og efternavn. Det var en praktisk foranstaltning for at sikre, at alle ville kunne tilgå kurset fra dag ét, men ingen af eleverne har bemærket, at de selv ville kunne ændre brugernavn. Desuden fremhæver en række udsagn med tilslutning fra 8 eller færre, at upload af besvarelser har været vanskelig. Det er også projektdeltagernes indtryk, da det i flere tilfælde har været nødvendigt at hjælpe elever med at få afleveringen på plads på rette sted og i rette format. 


\section{HumTek-M00C afprøvningen}

Kurset Introduktion til tangible computing blev afprøvet i slutningen af november 2014 med fire deltagere. Afprøvningssituationen var kunstig i forhold til den intenderede anvendelse af MOOC'en. Dels blev deltagerne rekrutteret til at teste og efterfølgende kommentere et produkt, frem for selv at opsøge MOOC'en ud fra et behov for at lære mere. Dels var forløbet tidsmæssigt meget kompakt (én dag), hvor der i konceptet er tænkt på et længere forløb, omend ikke udmålt i specifik tid, hvor deltagerne skal omsætte og anvende deres viden i forskellige trin. Dels foregik afprøvning på selve FabLab på RUC, hvor der i konceptet er tænkt en anvendelse enten et sted på campus (af studerende), eller i deltagerens hjem eller på arbejdspladsen (af iværksættere og andre interesserede).

Endvidere skal det nævnes, at deltagerne i kraft af særlig interesse for design af digitale produkter nok har fokuseret mere på funktionalitet og designmæssige forhold, end en udefra kommende bruger sandsynligvis ville gøre. Platformen for MOOC'en, som er Learning Management Systemet (LMS) Moodle, fik således nogle ord med på vejen om især navigation og brugervenlighed i forbindelse med at skrive indlæg i diskussionsfora. Til gengæld er det positivt, at deltagerne var i stand til selv at registrere sig som brugere og komme i gang. Samlet set giver kommentarerne til funktionaliteten dog anledning til overvejelser, om en MOOC, det skal være muligt at tilgå uden foregående instruktion, kræver en betjeningsmæssigt enklere platform end Moodle. Selv om Moodle som LMS-platform internationalt er særdeles populær og på mange punkter minder om andre LMS'er, har der historisk set har der været forskellig kritik af designet (fx. Padayachee, Kotzé \& Merwe, 2010; Senol, Gecili \& Onay Durdu, 2014). Da den åbne Moodle-platform er under konstant og hastig udvikling, er det ikke muligt umiddelbart at sammenholde den aktuelle afprøvnings resultater med tidligere publicerede brugervenlighedsundersøgelser.

En stor del af kritikken handler om MOOC'ens videosekvenser, der opleves som for lange og med for dårlig lyd. Ud fra et designmæssigt synspunkt er dette en berettiget og forventet kritik. Al erfaring tilsiger, at undervisningsvideoer skal være korte samt enkle og klare i budskabet. I den aktuelle sammenhæng var der imidlertid efter FabLabs ønske tale om et eksperiment med "lecture capturing", dvs. at optage en forelæsning og stille den til rådighed for brugere, som ikke kunne deltage i undervisningen i klasseværelset. Mens lecture capturing har nogen udbredelse, ikke mindst i USA, i regulære uddannelser, hvor studerende typisk bruger dem til at indhente det forsømte eller at repetere et pensum, antyder den aktuelle, noget spinkle afprøvning, at formatet ikke egner sig til enkeltstående forelæsninger, specielt ikke til workshop-deltagere og eksterne brugere, for hvem forelæsningen blot er et oplæg til selv at komme i gang med aktivt at fremstille et produkt. En føler sig endda fremmedgjort af selve det 
grundlæggende format med en underviser, som taler til en forsamling: "Det er henvendt til dem der sidder i salen, ikke til dem der sidder ved skærmen".

M00C'ens indhold får til gengæld ros. En respondent udbryder: "Indholdet er guld!" Slet så langt går de øvrige ikke, men to udtrykker dog, at kurset er "inspirerende". Sværhedsgraden, ikke mindst terminologien, ser imidlertid ud til at udgøre et problem. Kurset benytter ganske mange fagtermer, og deltagerne har ikke mulighed for at spørge direkte, når der er noget, de ikke forstår. En enkel måde at løse problemet på vil være at oprette en ordbog, gerne en hvor deltagerne selv kan bidrage, således at de studerende kan hjælpe hinanden og dermed arbejde aktivt med at omsætte deres viden. Men det vil naturligvis også være oplagt i højere grad at visualisere begreber, samt, naturligvis, at forklare dem på en enkel og tydelig måde i tekst og levende billeder.

\section{Sammenfatning}

Afprøvningen af de to MOOC-designs har været for begrænset til med blot nogenlunde sikkerhed at afgøre, i hvor høj grad konceptet lever op til de forestillinger, som ligger til grund for udviklingen af det. Men svarene fra elever og studerende har ikke desto mindre været opmuntrende.

Det overordnede formål har været at udvikle et redskab, som kan hjælpe uddannelsessøgende med at kvalificere studievalget. På dette punkt har tilbagemeldingerne fra gymnasieklassen været særdeles positive. Men det skal medtænkes, at der har været tale om ét forsøg i ét fag, som synes velegnet til formålet, og hvor motivationen har været drevet af en energisk underviser. Tidsforbruget, både for klassen (og for projektdeltagerne) har været betydeligt, og der kan være grund til at tvivle på, at formen vil vedblive med at være spændende, hvis den obligatorisk blev udbredt til alle eller flertallet af gymnasiets fag. En videre udvikling af konceptet bør se mere på at skabe et produkt til frivillig deltagelse i ekstracurriculære aktiviteter, mere i stil med den grundlæggende MOOC-tanke om, at interesserede selv opsøger information. Et sådant produkt vil fortsat kunne knyttes tæt til studievejledningen på det sekundære uddannelsesniveau som et redskab, studievejlederen kan henvise interesserede til. I en sådan form vil dette også være nogenlunde let for universitetet at håndtere M00C'en som et undervisningstilbud, der er tilgængeligt i bestemte perioder, inden de vordende studerende skal ansøge om optagelse på en videregående uddannelse.

Som læringsobjekt har begge MOOC-forsøg vist positive takter, men helt problemfrie er de ikke. SEM-MOOC har været udviklet i et samarbejde med SEM-personale, en ekspert i pædagogik fra UC Sjælland samt en gymnasielektor, der siden også påtog sig at afprøve produktet. I denne proces er der foregået en tilpasning, så kurset passer godt til undervisningsform og -niveau i gymnasiet, men ikke længere giver et fuldt 
realistisk indtryk af, hvad kravene er til en universitetsstuderende. Det faglige niveau er imidlertid solidt, og evalueringen viser éntydigt, at der har været et positivt læringsudbytte.

Trods sin uhensigtsmæssige form med optagelser af hele forelæsninger har HumTek-MOOC vist, at den kan opfylde et behov hos den del af målgruppen, som har haft adgang til den. Men her, som tilfældet også er med SEM-MOOC, har kurset ikke været gjort frit tilgængeligt som et formidlingsprodukt henvendt til den interesserede offentlighed. At en sådan formidling af universitetets viden er ønskelig og værdsat, peger selve MOOC-fænomenet på. Videre arbejde kan for eksempel koncentrere sig om, hvordan man udvikler MOOC-formidlingsprodukter til en regional målgruppe, samt ikke mindst hvordan man får denne i tale.

Endelig var det ambitionen at udvikle en særligt lødig form for markedsføring af universitet og fag. Med den begrænsede udbredelse, de to M00Cs har haft, er det ikke muligt at vurdere effekten, ud over at gymnasieeleverne, som naturligvis gennem deres lærers engagement har været særligt motiverede til at deltage i forsøget, har udtalt sig meget positivt om formen som et middel til at få bedre indsigt i et fag og en uddannelse, og i øvrigt også mere generelt til, hvad det vil sige at uddanne sig på et universitet.

\section{Tak til}

Professor Lars Hulgaard og specialkonsulent Nicolas Padfield, Roskilde Universitet og adjunkt Jesper Stage Petersen, University College Sjælland, som alle har bidraget til design og afprøvning af de to kursusforløb. Samt til studerende Jakob Christian Ipland for en kyndig og utrættelig indsats som medudvikler og senere underviser på SEM-MOOC. 


\section{Litteratur}

Albeck, G. (1984). Universitet og folk: bidrag til den folkelige universitetsundervisnings historie i Danmark med et udblik til folkeuniversiteterne i Norge og Sverige. København: Gyldendal.

Baker, R., \& Siemens, G. (2014). Educational data mining and learning analytics. In K. Sawyer (Ed.), Cambridge Handbook of the Learning Sciences, 2nd. ed. (pp. 253-271). New York: Cambridge University Press.

Barneveld, A. v., Arnold, K. E., \& Campbel, J. P. (2012). Analytics in Higher Education: Establishing a Common Language. ELI Paper, 2012(1). Retrieved January 27, 2015, from https://qa.itap.purdue.edu/learning/docs/research/ELI3026.pdf.

Bull, B. D. (2013, November 17). 10 Uses of MO0Cs for High School Students. Etale - Life in the Digital world. November 17. Retrieved July 21, 2014, from http://etale.org/main/2013/11/17/10-uses-of-moocsfor-high-school-students/.

Ferdig, R. E. (2013). What Massive Open Online Courses Have to Offer K-12 Teachers and Students. Lansing, MI Michigan Virtual Learning Research Institute. Retrieved July 25, 2014, from,http://media.mivu.org/institute/pdf/mooc_report.pdf.

Frenkel, K. A. (2013, February 19, 2013). Brown MOOC to Lure High School Students to STEM. Communications of the ACM News. Retrieved July 21, 2014, http://cacm.acm.org/news/161091-brown-mooc-to-lure-highschool-students-to-stem/.

Heilesen, S. B. (2012). Human Behaviors with Podcasts. In Z. Yan (Ed.), Encyclopedia of Cyber Behavior (Vol. 1, pp. 178-188). Hershey, PA: Information Science Reference.

Helms, N. H., \& Heilesen, S. B. (2011). Framing Creativity. User-driven Innovation in Changing Contexts. European Journal of Open, Distance and E-Learning (Special Themed Issue on Creativity and Open Educational Resources (OER)).

Henriksen, T. H. (2013). Profilmodel 2011. Unges forventede tidsforbrug på vej mod en erhvervskompetencegivende uddannelse. København: Ministeriet for Børn og Undervisning. Retrieved November 7, 2014, from:

http://www.uvm.dk/ /media/UVM/Filer/Stat/PDF13/130424\%20Pr ofilmodel $\% 202011 \% 20$ Forventet $\% 20$ tidsforbrug\%20paa $\% 20$ vej $\% 20$ mod\%20erhvervskompetencegivende\%20uddannelse_2.pdf.

Hjortdal, M. (2014, 10. september). Professionshøjskoler bruger 68 millioner kroner på reklamer, Politiken. Retrieved December 23, 2014 from http://politiken.dk/indland/uddannelse/ECE2391943/professionshoej skoler-bruger-68-millioner-kroner-paa-reklamer/. 
Ho, A. D., Reich, J., Nesterko, S., Seaton, D. T., Mullaney, T., Waldo, J., \& Chuang, I. (2014). HarvardX and MITx: The first year of open online courses. HarvardX and MITx Working Paper (Vol. 1, pp. 33). Cambridge, MA: Social Science Electronic Publishing. Retrieved December 22, 2014, from http://papers.ssrn.com/sol3/papers.cfm?abstract_id=2381263.

Holmegaard, H. T., Madsen, L. M., \& Ulriksen, L. (2014). Når forventningerne ikke stemmer overens med virkeligheden. En undersøgelse af de studerendes valg og strategier i overgangen til de længere videregående teknat-uddannelser. Dansk Universitetspædagogisk Tidsskrift, 9(16), 44-57.

Jackson, N. M. (2013). MOOCs go to K12: Higher ed trend expands to high schools. District Administration, August. Retrieved July 22, 2014 from http://www.districtadministration.com/article/moocs-go-k12-highered-trend-expands-high-schools.

Jordan, K. (2013). MOOC Completion Rates: The Data. Retrieved December 22, 2014, from http://www.katyjordan.com/MOOCproject.html.

Kedem, K., \& Puchalla, J. E. (2012). Shifting Ground: Technology Begins to Alter Centuries-Old Business Model for Universities: Moody's Investors Service. Retrieved January 16, 2014, from http://www.etsu.edu/125/taskforces/Programs_and_Opportunities/do cuments/MOOC.PDF.

Khan, S. (2011). Let's use video to reinvent education: TED. Retrieved December 22, 2014, from http://www.ted.com/talks/salman_khan_let_s_use_video_to_reinvent_e ducation.html.

Lawson, T., \& Comber, C. (2010). Videoconferencing in English schools: one technology, many pedagogies? Technology, Pedagogy \& Education, 19(3), 315-326.

Padayachee, I., Kotzé, P., \& Merwe, A. v. D. (2010). Course Management Systems from a Usability Perspective. Alternation, 17.

Perna, L., Ruby, A., Boruch, R., Wang, N., Janie Scull, C. E., \& Ahmad, S. (2013). The Life Cycle of a Million MOOC Users. Paper presented at the MOOC Research Initiative Conference, Austin, TX. Retrieved December 22, 2014, from http://www.gse.upenn.edu/pdf/ahead/perna_ruby_boruch_moocs_dec 2013.pdf.

Pritchard, A., Hunt, M., \& Barnes, A. (2010). Case study investigation of a videoconferencing experiment in primary schools, teaching modern foreign languages. Language Learning Journal, 38(2), 209-220.

Rottbøll, E. (2012, 17. oktober). Universiteter bruger millioner på reklamer, Information. Retrieved December 23, 2014 from http://www.information.dk/314163. 
Sarauw, L. L. (2014). Progression på tid og på tværs. Fremdrift og fleksibilisering som styringsregime på de videregående uddannelser Dansk Universitetspædagogisk Tidsskrift, 16, 6-17.

Schmid, J. (2013). Udformning af studietidsmodellen. København: Ministeriet for Forskning, Innovation og Videregående Uddannelser. Retrieved January 27, 2015 from http://medarbejdere.au.dk/fileadmin/www.medarbejdere.au.dk/Notat _om_studietidsmodellen.pdf.

Schulson, M. (2013, March 8). Online engineering course emphasizes interactive learning, The Brown Daily Herald. Retrieved July 24, 2014 from http://www.browndailyherald.com/2013/03/08/onlineengineering-course-emphasizes-interactive-learning/.

Senol, L., Gecili, H. \& Onay Durdu, P. (2014). Usability Evaluation of a Moodle based Learning Management System. In Proceedings of World Conference on Educational Multimedia, Hypermedia and Telecommunications 2014 (pp. 850-858). Chesapeake, VA: AACE.

Siemens, G. (2006). Knowing Knowledge. Retrieved December 22, 2014, from http://www.elearnspace.org/KnowingKnowledge_LowRes.pdf.

Siemens, G. (2012, July 25). MOOCs are really a platform. Elearnspace. Retrieved December 22, 2014, from http://www.elearnspace.org/blog/2012/07/25/moocs-are-really-aplatform/.

Siemens, G., \& Long, P. (2011). Penetrating the Fog: Analytics in Learning and Education. EDUCAUSE Review, 46(5), 31-40.

Ulriksen, L., Madsen, L. M., \& Tolstrup, H. (2011). Hvorfor bliver de ikke? Hvad fortæller forskningen om frafald på videregående STEMuddannelser? MONA, 2011(4), 35-55.

University of Edinburgh. (2013).MOOCs @ Edinburgh 2013 - Report \#1. Edinburgh: University of Edinburgh. Retrieved December 22, 2014, from https://www.era.lib.ed.ac.uk/bitstream/1842/6683/1/Edinburgh_MO OCs_Report2013_no1.pdf.

University of Edinburgh (2013, September 16). Free Online Courses Help Autistic Teenager. Retrieved July 22, 2014, from http://www.ed.ac.uk/about/edinburgh-global/newsevents/news/autistic-130913.

Van Deurs, K. L. S. (2013). Frafald på de videregående uddannelser. København: Ministeriet for Forskning Innovation og Videregående Uddannelser. Retrieved December 16, 2014 from http://ufm.dk/uddannelse-og-institutioner/statistik-oganalyser/frafald-studietid-fuldforelse/frafald-pa-de-videregaendeuddannelser.pdf.

Walter-Herrmann, J., \& Büching, C. (2013). FabLab: Of Machines, Makers and Inventors. Bielefeld: Transcript Verlag. 
Wilner, M. A. (2013, April 17, 2013). Brown University Creates Online Course for High School Students, New York Times, The Choice blog. Retrieved July 23, 2014 from http://thechoice.blogs.nytimes.com/2013/04/17/brown-universitycreates-a-mooc-for-high-schoolstudents/?_php=true\&_type=blogs\&_r=0. 